\title{
p53 expression in carcinoma of the cervix
}

\author{
C R Hunt, R J Hale, C H Buckley, J Hunt
}

\begin{abstract}
Aim-To assess overexpression of the proposed tumour suppressor gene product p53 using the mouse monoclonal antibody DO-7 in the three main subtypes of carcinoma of the uterine cervix and to evaluate its value as a prognostic indicator.

Methods-Eighty two cases of FIGO Stage IB/IIA uterine cervical carcinoma were studied retrospectively. The tumours had been previously typed into adenocarcinomas, squamous carcinomas and adenosquamous carcinomas after the tissue had been fixed in formalin and embedded in paraffin wax. p53 protein expression was assessed using a standard immunohistochemical technique and the findings were correlated with tumour type, lymph node status and clinical outcome.

Results-In total, the p53 gene product was overexpressed in $17.1 \%(14 / 82)$ of all carcinomas and also in areas of cervical intraepithelial neoplasia grade III adjacent to invasive squamous carcinoma. Where present, the normal epithelium was uniformly negative. No association was found between p53 overexpression and tumour subtype, lymph node status or clinical outcome.

Conclusions-It seems unlikely that p53 analysis will be of value in determining prognosis in carcinoma of the uterine cervix.

(F Clin Pathol 1996;49:971-974)
\end{abstract}

Keywords: cervical carcinoma, p53, prognosis.

Department of

Reproductive

Pathology, St Mary's

Hospital, Manchester

C R Hunt

C H Buckley

\section{Department of}

Histopathology,

Stepping Hill Hospital, Stockport

R J Hale

\section{Department of \\ Neuroscience, \\ University of \\ Manchester, \\ Manchester \\ J Hunt}

Correspondence to: Dr C R Hunt, Department of Reproductive Pathology,

St Mary's Hospital for

Women and Children,

Whitworth Park,

Manchester M13 0JH.

Accepted for publication

4 September 1996 events has not been elucidated fully, loss function is believed to play an important role in the pathogenesis of carcinomas of the uterine cervix, ${ }^{9}$ where it has been shown that the p53 gene product may be inactivated in three prin- cipal ways: after (1) somatic point mutation ${ }^{10}$; (2) loss of heterozygosity ${ }^{11}$; and (3) following human papillomavirus (HPV) infection, as the viral oncoprotein E6 is known to bind to, stabilise and ultimately degrade wild type p53. ${ }^{12}$

In this study, we have used a mouse monoclonal antibody (DO-7) to examine the overexpression of the $\mathrm{p} 53$ gene product in stage IB/IIA cervical carcinomas and have correlated our findings with lymph node status and clinical outcome in order to assess the value of p53 as a prognostic indicator.

\section{Methods}

Eighty two cases of FIGO stage IB/IIA cervical carcinoma, which had been treated by Wertheim's hysterectomy without prior radiotherapy, were selected from the files of the Department of Reproductive Pathology at St Mary's Hospital, Manchester, UK.

The tissue had been fixed in formalin, routinely processed and embedded in paraffin wax. The carcinomas were typed according to the criteria of Buckley and Fox ${ }^{13}$ using haematoxylin and eosin stained sections and periodic acid Schiff/alcian blue staining, with and without diastase predigestion.

A microwave antigen retrieval method was used and sections were irradiated at $750 \mathrm{~W}$ for 20 minutes in 1 litre of citrate buffer ( $\mathrm{pH} \mathrm{6.0)}$. For immunohistochemical staining, sections were dewaxed in xylene and a standard avidin biotin immunoperoxidase technique was applied. The sections were first incubated with normal goat serum at room temperature for 20 minutes, to reduce background staining, and then with anti-p53 mouse monoclonal antibody, DO-7 (Novocastra Laboratories, Newcastle upon Tyne, UK), diluted 1 in 100 in phosphate buffered saline at room temperature for 60 minutes. A colorectal adenocarcinoma with known overexpression of the p53 gene product was used as a positive control. Negative controls, involving substitution of the primary antibody with rabbit serum, were included for all cases.

The percentage of tumour cells staining positively was assessed using a semiquantitative technique: tumours in which there was nuclear positivity in at least $10 \%$ of the neoplastic cells were regarded as positive; those tumours with only focal or no nuclear staining were regarded as negative. Note was made of lymph node status (lymph node metastases absent or present) and clinical outcome (alive and well; alive with recurrent disease; died of disease). In all cases a minimum of five years follow up was available. The results were analysed using a $\chi^{2}$ test, with Yates's correction where appropriate, and Fisher's exact test with the SAS statistical 


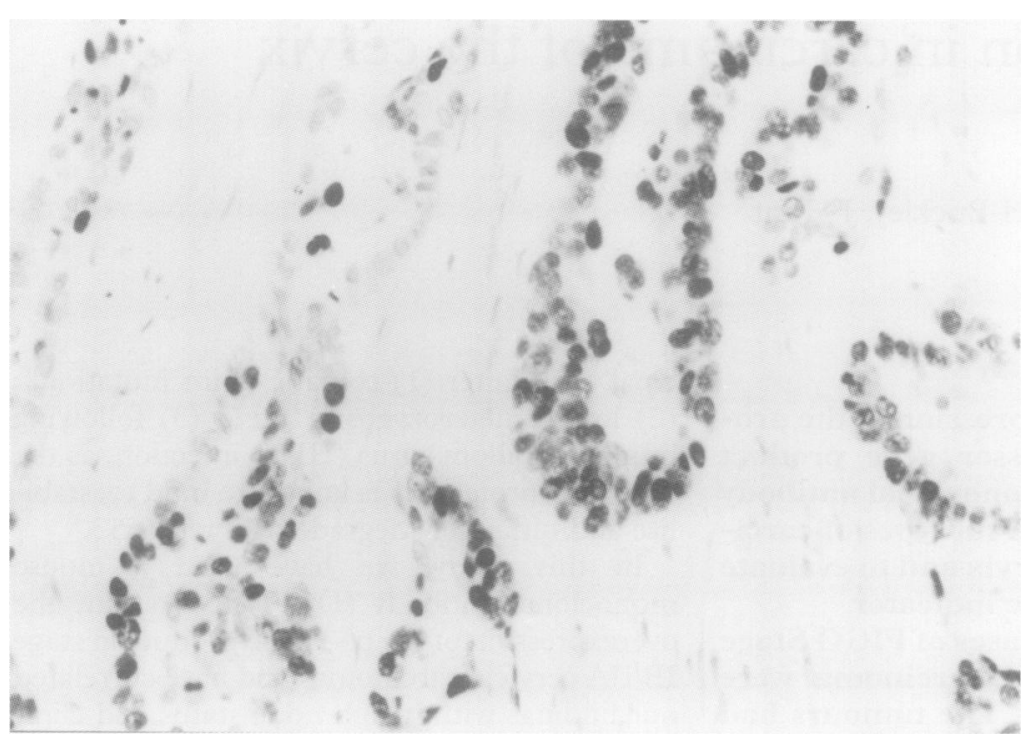

Figure 1 Positive nuclear staining for $p 53$ in a well differentiated adenocarcinoma of the uterine cervix. tivity in any of the tumours. The number of the tumour subtypes containing more than focal positivity is shown in table 1 . Most of the cases deemed to be negative contained no positive cells. Scattered, focal nuclear positivity was present, however, in 10 cases (three squamous carcinomas, three adenocarcinomas and four adenocarcinomas). Only three tumours in total (two adenocarcinomas and one adenosquamous carcinoma) contained more than $50 \%$ positive cells.

p53 overexpression was seen in epithelium which contained cervical intraepithelial neoplasia (CIN) grade III adjacent to invasive squamous carcinoma, but not in epithelium containing CIN grade I or II, cervical glandular intraepithelial neoplasia (CGIN), or in any normal epithelium present. In the foci of CIN III, isolated positive cells were present at all levels within the surface squamous epithelium. The stromal cells were negative.

No association was found between p53 overexpression and cervical carcinoma overall, the individual tumour subtypes, lymph node status or clinical outcome (table 2).

\begin{tabular}{lll}
\hline & $p 53$ staining (\%) \\
\cline { 2 - 3 } Tumour type & Positive & Negative \\
\hline $\begin{array}{l}\text { Squamous carcinoma } \\
(\mathrm{n}=22)\end{array}$ & $5(22.7)$ & $17(77.3)$ \\
$\begin{array}{l}\text { Adenosquamous } \\
\text { carcinoma }(\mathrm{n}=25)\end{array}$ & $4(16.0)$ & $21(84.0)$ \\
$\begin{array}{l}\text { Adenocarcinoma }(\mathrm{n}=35) \\
\text { Overall }(\mathrm{n}=82)\end{array}$ & $5(14.3)$ & $30(85.7)$ \\
\hline
\end{tabular}

Table 2 Percentage death rate with respect to $p 53$ staining in patients with and without lymph node metastases in each tumour type and overall

\begin{tabular}{lcc}
\hline & & \\
& & \\
& & \\
\cline { 2 - 3 } Tumour staining & \\
\cline { 2 - 3 } & Positive & Negative \\
\hline Lymph node metastases present & & \\
Squamous carcinoma & $25 \%(1 / 4)$ & $50 \%(3 / 6)$ \\
Adenosquamous carcinoma & $100 \%(1 / 1)$ & $22 \%(3 / 11)$ \\
Adenocarcinoma & $0 \%(0 / 1)$ & $55 \%(6 / 11)$ \\
Overall & $33 \%(2 / 6)$ & $43 \%(12 / 28)$ \\
Lymph node metastases absent & & \\
Squamous carcinoma & $100 \%(1 / 1)$ & $22 \%(3 / 11)$ \\
Adenosquamous carcinoma & $67 \%(2 / 3)$ & $10 \%(1 / 10)$ \\
Adenocarcinoma & $0 \%(0 / 4)$ & $5 \%(1 / 19)$ \\
Overall & $38 \%(3 / 8)$ & $13 \%(5 / 40)$ \\
Total & & \\
Squamous carcinoma & $40 \%(2 / 5)$ & $35 \%(6 / 17)$ \\
Adenosquamous carcinoma & $75 \%(3 / 4)$ & $19 \%(4 / 21)$ \\
Adenocarcinoma & $0 \%(0 / 5)$ & $23 \%(7 / 30)$ \\
Overall & $36 \%(5 / 14)$ & $25 \%(17 / 68)$ \\
\hline
\end{tabular}

package. A significant correlation between two parameters was taken at the $95 \%$ confidence limit, where $\mathrm{p}<0.05$.

\section{Results}

Each of the three most frequent tumour subtypes (squamous, adenosquamous and adenocarcinoma) were represented as different tumour types having different behaviour patterns. ${ }^{14}$ Twenty cases of squamous carcinoma, 25 adenosquamous carcinomas and 35 adenocarcinomas were studied. Overall, there was p53 overexpression in $17.1 \%(14 / 82)$ of the carcinomas, demonstrated by granular nuclear positivity (fig 1). There was no evidence of cytoplasmic or membranous posi-

\section{Discussion}

The pathogenesis of carcinoma of the uterine cervix is thought to occur through a multistep process but further work is still required to clarify the exact mechanism. Attention has been focused on a number of possible cofactors including cigarette smoking, ${ }^{15}$ immunodeficiency, ${ }^{15}$ HLA subtypes, ${ }^{16}$ certain HPV subtypes, ${ }^{17}$ and the proposed tumour suppressor gene $\mathrm{p} 53,{ }^{18}$ as loss of $\mathrm{p} 53$ function is the commonest genetic alteration involved in human malignancies.

The mouse monoclonal antibody DO-7 was chosen to examine p53 overexpression in uterine cervical carcinoma as it had been demonstrated to be the most specific and sensitive antibody directed against p53 protein when used on paraffin wax embedded tissue. ${ }^{19}$

p53 gene product has been shown to be overexpressed in cervical carcinoma as a whole and in its three main tumour subtypes to varying extents. ${ }^{20-23}$ Our value of $17.1 \%(14 / 82)$ obtained for the total number of carcinomas containing more than $10 \%$ immunoreactive tumour cells is in keeping with the majority of the published data-for example, 25.5\% (Oka et $a l),{ }^{24} 20.2 \%$ (Kainz et $\left.a l\right)^{25}$ and $14.0 \%$ (Busby-Earle et al). ${ }^{26}$ However, a wide range of figures does exist, with one study claiming up to $74 \%$ positivity in squamous carcinomas. ${ }^{27}$ Within the individual tumour subtypes of our study, $22.7 \%$ of squamous carcinomas, $16.0 \%$ of adenosquamous carcinomas and $14.3 \%$ of adenocarcinomas were regarded as positive. Assessment of p53 overexpression by immunoreactivity has only been described once previously in adenosquamous carcinoma where $57 \%$ (four of seven) of tumours were stated as being positive. ${ }^{21}$ In adenocarcinomas of the uterine cervix, $11 \%$ (four of 36 ), ${ }^{20} 44 \%$ (four of nine) $)^{21}$ and $100 \%$ (one of one) ${ }^{27}$ have been shown to contain cells overexpressing p53 protein. In the present study there was no sig- 
nificant difference between the individual tumour subtypes with respect to p53 protein expression.

Only three of the tumours studied (two adenocarcinomas and an adenosquamous carcinoma) contained more than $50 \%$ positive cells. Using the same antibody and a similar method, Lambkin et $a l^{2}$ found that seven of 55 cervical squamous carcinomas had more than $50 \%$ positive cells. They stated that microwave pretreatment significantly increased both the numbers of tumours and the number of individual cells within any particular tumour showing p53 immunoreactivity.

We were able to demonstrate p53 immunoreactivity in those areas of CIN III adjacent to invasive components, as has been described, ${ }^{27}$ but foci of CGIN and the normal epithelium included were negative. Holm et $a l^{20}$ found all grades of CIN and CGIN to be negative for p53 and suggested that alteration in p53 protein expression is not an early event in the pathogenesis of cervical neoplasia. Bosari et $a l^{7}$ observed that the "distribution of p53immunoreactive cells paralleled the extension of dysplastic changes in the squamous epithelium" and suggested that p53 immunoreactivity may precede the development of tumours with a fully malignant and invasive phenotype. The presence of focal positive cells in an otherwise negative tumour may be due to increased p53 expression in cells undergoing DNA repair. ${ }^{28}$ Another explanation is alteration in mdm-2 gene expression. ${ }^{29}$ Wild type p53 is known to be bound by mdm-2 oncogene product in vitro and it is possible that overexpression of mdm-2 has resulted in accumulation of detectable $\mathrm{p} 53$ gene product.

The degradation of the p53 gene product after binding to the E6 viral protein in cells infected with high risk HPV subtypes may play a fundamental role in the development of cervical carcinoma. ${ }^{12}$ It may therefore be considered a deficiency of this study that HPV analyses were not performed. Alternatively, Butz et $a l^{30}$ have demonstrated that $\mathrm{p} 53$ does not seem to be regularly inactivated in HPV positive cancer cells. It has also been shown that p53 mutations are rare in some HPV negative cervical carcinomas ${ }^{31}$ and that there is no consistent correlation between p53 mutations and HPV status. ${ }^{26}$ These conflicting findings indicate that mechanisms other than HPV infection and p53 mutation must come into play to cause functional inactivation of $\mathrm{p} 53$. Further studies are therefore necessary to clarify the exact role of the p53 gene product and high risk HPV subtypes in the pathogenesis of cervical carcinoma.

To our knowledge, only two previous studies have examined the prognostic value of p53 protein overexpression in surgically treated early stage carcinomas of the uterine cervix. ${ }^{2125}$ Our findings were similar; there was no relation between p53 overexpression and prognosis in the uterine cervix. Kainz $e t a l^{25}$ used the monoclonal antibody BP53-12 on 109 cases of squamous carcinoma and found no relation to prognosis. Work from the same institute also failed to demonstrate that p53 overexpression was of prognostic value in advanced, stage III squamous cervical carcinoma. ${ }^{32}$ Similar findings were obtained by Oka et $a l^{4}$ using the polyclonal antibody CM1 on stage III squamous carcinoma. Helland et $a l^{11}$ found no relation between p53 protein expression and prognosis in 92 stage I-IV cervical carcinomas, also using the CM1 antibody. The latter is the only other study to correlate p53 protein expression with prognosis in adenocarcinoma and adenosquamous carcinoma by immunohistochemistry, although smaller numbers were involved and the disease stage for tumour subtypes was not specifically stated. Helland $e t a l^{1}$ found that $55 \%(51 / 92)$ of carcinomas were positive, but p53 protein expression was only detected in less than $5 \%(45 / 51)$ of the tumour cells in the majority of cases. As false tumour positivity does occur ${ }^{33}$ and there is a close relation between high levels of $\mathrm{p} 53$ overexpression and neoplasia, ${ }^{34}$ the validity of such observations based on results from tumours with only a small number of positive cells is difficult to assess.

These differences in interpretation highlight the problem of correlating results from different immunohistochemical studies involving antibodies directed against $\mathrm{p} 53$. As protocols have not been standardised, it is perhaps not possible to draw conclusions from comparisons of studies where the tumour stages, antibodies, fixation processes, antigen unmasking techniques, the determination of tumour cell positivity qualitatively and quantitatively, and statistical analysis have varied considerably.

In a recent review of the value of $\mathrm{p} 53$ overexpression as an indication of poor prognosis in human malignancies, Dowell and $\mathrm{Hall}^{35}$ concluded that while p53 is of undisputed importance in our understanding of oncogenesis and neoplasia, it is probably only a weak prognostic factor; observations in keeping with our findings. The p53 protein does indeed seem to play a pivotal role in the pathogenesis of carcinoma of the cervix but, despite the relatively small numbers involved in this series, there is no evidence to suggest that its overexpression may be useful as a prognostic indicator. Traditional parameters such as tumour size and lymph node status ${ }^{14}$ still seem to be the most important determinants of prognosis in carcinoma of the uterine cervix.

We are grateful to Mr David Haughton, University of Manchester, for performing the statistical analyses.

1 Levine AJ, Momand J, Finlay CA. The p53 tumour suppressor gene. Nature 1991;351:453-6.

2 Finlay CA, Hinds PN, Levine AJ. The p53 proto-oncogen can act as a suppressor of transformation. Cell 1989;57: 1083-93.

3 Hollstein M, Sidransky D, Vogelstein B, Harris CC. p53 mutations in human cancers. Science 1991;253:49-53.

4 Bartek J, Bartkova J, Vojtesek B, Stakova Z, Lukas J, Rejthar $\mathrm{A}$, et al. Aberrant expression of the p 53 oncoprotein is a common feature of a wide spectrum of human malignan ies. Oncogene 1991;6:1699-703.

5 Levine AJ, Perry ME, Chang A, Silver A, Dittmer D, Wu M et al. The 1993 Walter Hubert Lecture: the role of the p53 tumour suppressor gene in tumorigenesis. $\mathrm{Br} F \mathrm{Cancer}$ 1994;69:409-16.

6 Starzynska T, Bromley M, Gosh A, Stern PL. Prognostic significance of p53 over-expression and c-Ki-ras mutation in colorectal cancer. Gastroenterology 1993;104:57-64.

7 Vijeyasingam R, Darnton SJ, Jenner K, Allen CA, Billingham C, Matthews HR. Expression of $\mathrm{p} 53$ protein in 
oesophageal carcinoma: clinicopathological correlation and prognostic significance. Br $\mathcal{F}$ Surg 1994;81:1623-6.

8 Barnes DM, Dublin EA, Fisher CJ, Levison DA, Millis RA. Immunohistochemical detection of $\mathrm{p} 53$ protein in mammary carcinoma: an important new independent indicator of prognosis? Hum Pathol 1993;24:469-79.

9 Miwa K, Miyamoto S, Kato H, Imamura T, Nishida $M$, Yoshikawa $Y$, et al. The role of p53 inactivation in human cervical cell carcinoma development. Br f Cancer 1995;71: 219-26.

10 Crook T, Wrede D, Tidy JA, Mason WP, Evans DJ, Vousden $\mathrm{KH}$. Clonal p53 mutations in primary cervical cancer: association with human papillomavirus negative tumours. Lancet 1992;339:1070-3

11 Park SY, Kang YS, Kim BG, Lee SH, Lee ED, Lee KH, et al. Loss of heterozygosity on the short arm of chromosome 17 in uterine cervical carcinoma. Cancer Genet Cytogenet 1995; 79:74-8.

12 Scheffner M, Werness BA, Huibregtse JM, Levine AJ, Howley PM. The E6 oncoprotein encoded by human papilley PM. The E6 oncoprotein encoded by human papil-
lomavirus type 16 and 18 promotes the degradation of 553 . lomavirus type 16 and 18

13 Buckley CH, Fox H. Carcinoma of the cervix. In: Anthony PP, MacSween RNM, eds. Recent advances in histopathology. Vol 14. London: Churchill Livingstone, 1989:63-78.

14 Hale RJ, Wilcox FL, Buckley CH, Tindall VR, Ryder WDJ, Logue JP. Prognostic factors in uterine cervical carcinoma: a clinico-pathological analysis. Int $f$ Gynecol Cancer 1991;1:19-23.

15 Bornstein J, Rahat MA, Abramovici H. Etiology of cervical cancer: current concepts. Obstet Gynecol Surv 1995;50: $146-54$

16 Wank R, Thomssen C. High risk of squamous cell carcinoma of the cervix for women with HLA-DQw3. Nature 1991;352:723-5.

17 Gupta JW, Saito K, Fu YS, Shah K. Human papillomaviruses and the pathogenesis of cervical neoplasia. Cancer 1989;64:2104-10.

18 Blondal JA, Benchimol S. The role of $\mathrm{p} 53$ in tumor progression. Semin Cancer Biol 1994;5:177-86.

19 Baas IO, Mulder JR, Offerhaus GFA, Vogelstein B, Hamilton SR. An evaluation of six antibodies for immunohistochemistry of mutant p53 gene product in archival histochemistry of mutant p53 gene product

20 Holm R, Skomedal H, Helland A, Kristensen G, Borresen AL, Nesland JM. Immunohistochemical analysis of p53 protein overexpression in normal, premalignant and malignant tissues of the cervix uteri. 7 Pathol 1993;169:21-6.
21 Helland A, Holm R, Kristensen G, Kaern J, Karlsen F, Trope C, et al. Genetic alterations of the TP53 gene, p53 protein expression and HPV infection in primary cervical carcinomas. F Pathol 1993;171:105-14.

22 Lambkin HA, Mothersill CM, Kelehan P. Variations in immunohistochemical detection of $\mathrm{p} 53$ protein overexpression in cervical carcinomas with different antibodies and different methods of detection. ₹ Pathol 1993;172:13-18.

23 Paquette RL, Lee YY, Wilczynski SP, Karmakar A, Kizaki $M$, Miller CW, et al. Mutations of $\mathrm{p} 53$ and human papillomavirus infection in cervical carcinoma. Cancer 1993;72: 1272-80.

24 Oka K, Nakano T, Arai T. p53CM1 expression is not associated with prognosis in uterine cervical carcinoma. Cancer 1993;72:160-3.

25 Kainz C, Kohlberger P, Gitsch G, Sliutz G, Breitenecker G, Reinthaller A. Mutant $\mathrm{p} 53$ in patients with invasive cervical cancer stages IB to IIB. Gynecol Oncol 1995;57:212-14.

26 Busby-Earle RMC, Steel CM, Williams ARW, Cohen B, Bird CC. p 53 mutations in cervical carcinogenesis - low frequency and lack of correlation with human papillomavirus status. Br f Cancer 1994;69:732-7.

27 Bosari S, Roncalli M, Viale G, Bossi P, Coggi G. p53 immunoreactivity in inflammatory and neoplastic diseases of the uterine cervix. f Pathol 1993;169:425-30.

28 Lane DP. p53, guardian of the genome. Nature 1992;358: 15-16.

29 Oliner JD, Kinzler KW, Meltzer PS, George DL, Vogelstein B. Amplification of a gene encoding a p53-associated protein in human sarcomas. Nature 1992;358:705-8.

30 Butz K, Shahabeddin L, Giesen C, Spitkovsky D, Ullman A, Hoppe-Seyler F. Functional p53 protein in human papillomavirus-positive cancer cells. Oncogene 1995;10: 927-36.

31 Park DJ, Wilczynski SP, Paquette RL, Miller CW, Koeffler HP. p53 mutations in HPV-negative cervical carcinoma. Oncogene 1994;9:205-10.

32 Gitsch G, Kainz C, Joura E, Beitenecker G. Mutant p53 in patients with stage III cervical cancer. Anticancer Res 1992; $12: 2241-2$.

33 Wynford-Thomas D. p53 in -tumour pathology: Can we trust immunocytochemistry? $\mathcal{F}$ Pathol 1992;166:329-30.

34 Hall PA, Lane DP. p53 in tumour pathology: Can we trust immunohistochemistry?... Revisited! f Pathol 1994;172:1-4.

35 Dowell SP, Hall PA. The p53 tumour suppressor gene and tumour prognosis: Is there a relationship? $\mathscr{f}$ Pathol 1995;177:221-4. 